\section{Original Article}

Dr. Shahana Dastagir Sunny BDS, MPhil

Assoc. Professor \& Head Dept. of Dental Public Health City Dental College, Dhaka

Dr. Behetarin Israt BDS, MS (OMFS) Asst. Professor Dept. of Pediatric Dentistry City Dental College, Dhaka

\section{Dr. Arup Kumar Saha} BDS, MPH Asst. Professor Dept. of Dental Public Health

City Dental College, Dhaka

\section{Dr. Akashlynn Badruddoza Dithi BDS Lecturer Dept. of Science of Dental Materials City Dental College, Dhaka \\ Prof. Dr. Farida Illius BDS, DDS Professor \& Head Dept. of Periodontology, Oral Pathology \& Oral Medicine \\ City Dental College, Dhaka}

Correspondence to:

Dr. Shahana Dastagir Sunny BDS, MPhil

Assoc. Professor \& Head Dept. of Dental Public Health

City Dental College, Dhaka Mob: +8801712486548 E-Mail: dr.sunny71@yahoo.com

\title{
Oral Health Status of the Arsenic Exposed and Non-Exposed Children in Bangladesh
}

\begin{abstract}
:
Aims: This cross-sectional study was conducted in rural areas of Bangladesh to assess and compare the state of oral health among the arsenic exposed population affected through drinking water with the non-exposed group.
\end{abstract}

Materials and Methods: A total of 400 respondents were interviewed and examined through a structured questionnaire and a checklist. Exposed group was included with or without the signs of arsenicosis.

Results: Among them, 200(50\%) were found exposed to arsenic and the rest $200(50 \%)$ were in non-exposed group. Study showed that $6 \%$ respondents were suffering from sensitivity of teeth, and $24.5 \%$ and $20 \%$ developed pigmentation on gingival and tongue surfaces, respectively, who used to take arsenic contaminated water, in comparison to non-exposed group, $10.9 \%, 5 \%, 0.5 \%$, respectively. Arsenic exposed group had tooth abrasion $24 \%$, while it was $4.5 \%$ in non-exposed group. Less caries (18.5\%) was found among the arsenic exposed group than the non-exposed group (25.9\%).

Conclusion: Arsenic might have influence on enamel hypoplasia and this low tendency of occurring carries.

Key words: Arsenic, arsenic exposed and non-exposed patients, arsenicosis.

\section{Introduction:}

In Bangladesh, arsenic poisoning has been one of the biggest environmental health and social disasters of recent times. About seventy million people of Bangladesh are exposed to toxic levels of arsenic $(>0.05 \mathrm{mg} / \mathrm{L})$ in drinking water. ${ }^{1}$ Use of tube well water has been tremendously increased for last 10 years considering it is a safe drinking water. Based on knowledge and practice, $97 \%$ people of Bangladesh now depend on tube well water both for drinking and domestic purpose.${ }^{4}$ It is ironic that "millions of people have been exposed to inorganic arsenic in Bangladesh through drinking water, which is mostly pumped out through the tube well water and millions of people are at risk of dying from this geological genocide. ${ }^{15}$

Usually there are four types of arsenic compounds existing in water. These are arsenite, arsenate, monomethyl arsenic acid and dimethyl arsenic acid. But in the ground water, arsenic predominantly occurs in the triand pentavalent form. These two are found in ground water of Bangladesh and west Bengal. The arsenic contamination of ground water in Bangladesh described as one of the largest arsenic calamities in the world, where a major proportion of the tube wells have been contaminated with arsenic at level that exceeds both WHO guide line of $10 \mathrm{mg} / \mathrm{L}$ and the Bangladesh level of $50 \mathrm{mg} / \mathrm{L}^{3}$ Mouth is highly accessible part of the body and also sensitive to and able to reflect changes occurring internally. Nakorn $\mathrm{Si}$ Thammarat Province suggested that people lived in arsenic endemic areas had higher prevalence of enamel hypoplasia. ${ }^{2}$ As children fall on easy prey to all infection and infestation, so any disturbance may occur during the developing stage of the teeth, may also affect the oral cavity of children. ${ }^{6}$ 
The aim of the present study was to explore the effect of arsenic exposure through the drinking water to oral health in a Bangladeshi population.

\section{Materials and Methods:}

This cross-sectional comparative study was conducted to compare the status of oral health among the arsenic exposed and non-exposed population from the villages named Kazir nagar, Maher, Voldighi, Malora of Shaharasti Upazilla of Chandpur District and village Jangalia of Gazipur Upazilla of Dhaka district of Bangladesh.

Study Design: A cross-sectional study with comparison group that included the following comparison groups.

\section{a. Arsenic exposed group:}

Children exposed to arsenic contaminated water with or without having arsenicosis manifestation.

\section{b. Arsenic non-exposed group:}

Children of parents not having consumed tube well water whose arsenic content was in excess of $0.05 \mathrm{mg} / \mathrm{L}$. Criteria for recruitment of participants for different groups-

\section{Arsenic exposed Group:}

Inclusion criteria -

i. Children of age group from 5-13 years.

ii. Male and female.

iii. The house-hold drinking water source having arsenic in excess of $0.05 \mathrm{mg} / \mathrm{L}$.

iv. History of collecting drinking water from arsenic contaminated source for attack a period of 5 years.

\section{Exclusion Criteria -}

i. Children aged less than 5 years or more than 13 years.

ii. Children who had spent a period of 6 months or more outside his or her parental residence.

Reference/ Comparison Group:

\section{Inclusion criteria -}

i. Children of age group 5-13 years.

ii. Both sexes.

iii. Children having no sign of arsenicosis.

iv. Children no history of having consumed tube well water that contained arsenic in excess of $0.05 \mathrm{mg} / \mathrm{L}$ since his or her birth.

\section{Exclusion Criteria -}

i. Children aged less than 5 years or more than 13 years. Children having evidence of consumed tube well water that contained arsenic more than $0.05 \mathrm{mg} / \mathrm{L}$.

ii. Children who had spent a period of 6 months or more outside his or her parents resident during his or her life time.

Study Period: One year (July 2006 to June 2007). Study Population: Children taking water containing arsenic $>0.05 \mathrm{mg} / \mathrm{L}$ with or without the sign of melanosis and keratosis were considered as the arsenic exposed people and children taking water containing $<0.05 \mathrm{md} / \mathrm{L}$ as non-exposed.

Sample Size: Sample size determination criteria by the following formula for sample situation was:-

$a=z_{1}^{2}-\alpha / 2\left[p_{1}\left(1-p_{1}\right)+p_{2}\left(1-p_{2}\right)\right] / d^{2}$

Where, $Z=z$ score $=1.96$

$d=$ acceptable level of error $=0.10$

$p_{1} \& p_{2}=$ the anticipated population of adverse effect of oral health status in arsenic exposed and non-exposed population were set at $50 \%$ i.e. 0.5 because of available literature does not provide any estimation of the anticipated prevalence rate. The 0.5 for were to provide the largest sample size. However it had been taken comparatively large value for error $(d)=.10$ to keep the sample to a manageable size $=192.08$ or 193 by using above mentioned formula. In this study, the inflation of the sample size by an arbitrary figure of 7 as a check against possible drop out due to inconsistency or incomplete questionnaire and refusal of participation of respondents. Thus the final sample size was $200+201=401$

Sample Technique: Purposively according to selection criteria.

Results:

A total of 401 respondents were interviewed and examined through structured questionnaire and checklist, and accordingly the data were collected. The findings were as follows-

Table-1: Distribution of the Respondents by age.

\begin{tabular}{||c|c|c|c||}
\hline \hline Age Group (years) & $\begin{array}{c}\text { Arsenic exposed } \\
\text { group }\end{array}$ & $\begin{array}{c}\text { Arsenic non-exposed } \\
\text { group }\end{array}$ & Total \\
\hline \multirow{2}{*}{5} & 24 & 16 & 40 \\
& $(12)$ & $(8)$ & $(10)$ \\
\hline \multirow{2}{*}{$5-12$} & 140 & 165 & 305 \\
& $(70)$ & $(82.5)$ & $(76.1)$ \\
\hline \multirow{2}{*}{$12-13$} & 36 & 10 & 56 \\
& $(18)$ & $(10)$ & $(14)$ \\
\hline Total & 200 & 201 & 401 \\
\hline
\end{tabular}

Mean $\pm S D=9.57 \pm 2.547$ (exposed); $9.25 \pm 2.547$ (nonexposed). Age group: $5-13$ years.

Table- 1 shows the age distribution of the respondents among the arsenic exposed and non-exposed groups. Here 5 years indicates the early erupting age group and $>5-12$ years for mixed dentition. The mean age of respondents were found $9.57(\mathrm{SD} \pm 2.547)$ years and $9.25(\mathrm{SD} \pm 2.547)$ years. In the arsenic exposed group, the highest proportion of respondents $(70 \%)$ were belong to $>5-12$ years, followed by $18 \%$ in the $>12-13$ years age group. Among the arsenic non-exposed group, $82.1 \%$ were in the age group of $>5-12$ years and followed by $10 \%$ in the $>12-13$ years. So, the group codes were similar in terms of age. 
Table-2: Distribution of Respondents by oro-dental problem as Sensitivity of Teeth.

\begin{tabular}{|c|c|c|c|c|c|}
\hline \multirow{2}{*}{$\begin{array}{l}\text { Categories according } \\
\text { to Arsenic exposure }\end{array}$} & \multicolumn{3}{|c|}{ Oro-dental problem as Sensitivity of Teeth } & \multirow{2}{*}{$\begin{array}{c}\text { Test of } \\
\text { significance }\end{array}$} & \multirow{2}{*}{ Comment } \\
\hline & Yes & No & Total & & \\
\hline Exposed group & $\begin{array}{l}12 \\
(6)\end{array}$ & $\begin{array}{l}188 \\
(94)\end{array}$ & $\begin{array}{l}200 \\
(3.5)\end{array}$ & $\begin{array}{c}X_{(1)}^{2}=7.453 \\
P<0.05\end{array}$ & Significant \\
\hline Non-exposed group & $\begin{array}{c}2 \\
\text { (1) }\end{array}$ & $\begin{array}{l}199 \\
(99)\end{array}$ & 201 & & - \\
\hline Total & 14 & 387 & 401 & $\cdot$ & $\cdot$ \\
\hline
\end{tabular}

Teeth sensitivity was found $6 \%$ among the arsenic exposed group and $1 \%$ among the non-exposed group (table-2). The differences in the proportion of having teeth sensitivity among the arsenic exposed and nonexposed groups were found statistically significant by Pearson Chi-Square $\left(x^{2}\right)$ at $1 \mathrm{df}$.

Table-3: Distribution of Respondents by oro-dental problem as Gingival Pigmentation.

\begin{tabular}{|c|c|c|c|c|c|}
\hline \multirow{2}{*}{$\begin{array}{l}\text { Categories according } \\
\text { to Arsenic exposure }\end{array}$} & \multicolumn{3}{|c|}{$\begin{array}{l}\text { Oro-dental problem as } \\
\text { Gingival Pigmentation }\end{array}$} & \multirow{2}{*}{$\begin{array}{c}\text { Test of } \\
\text { significance }\end{array}$} & \multirow{2}{*}{ Comment } \\
\hline & Yes & No & Total & & \\
\hline Exposed group & $\begin{array}{c}49 \\
(24.5)\end{array}$ & $\begin{array}{c}151 \\
(75.5)\end{array}$ & 200 & $\begin{array}{c}X_{(1)}^{2}=12.641 \\
P<0.001\end{array}$ & Significant \\
\hline Non-exposed group & $\begin{array}{c}22 \\
(10.9)\end{array}$ & $\begin{array}{c}179 \\
(89.1)\end{array}$ & 201 & $\cdot$ & - \\
\hline Total & 71 & 330 & 401 & $\cdot$ & - \\
\hline
\end{tabular}

Gingival pigmentation was found more (24.5\%) among the arsenic exposed group and less (10.9\%) among the non-exposed group (table-3). The differences in the proportion of having gingival pigmentation among the arsenic exposed and non-exposed groups were found statistically significant by Pearson Chi-Square $\left(x^{2}\right)$ at $1 \mathrm{df}$.

Table-4: Distribution of Respondents by oro-dental problem as Pigmentation on Tongue.

\begin{tabular}{|c|c|c|c|c|c|}
\hline \multirow{2}{*}{$\begin{array}{l}\text { Categories according } \\
\text { to Arsenic exposure }\end{array}$} & \multicolumn{3}{|c|}{$\begin{array}{l}\text { Oro-dental problem as } \\
\text { Pigmentation on Tongue }\end{array}$} & \multirow{2}{*}{$\begin{array}{c}\text { Test of } \\
\text { significance }\end{array}$} & \multirow{2}{*}{ Comment } \\
\hline & Yes & No & Total & & \\
\hline Exposed group & $\begin{array}{l}40 \\
(20)\end{array}$ & $\begin{array}{l}160 \\
(80)\end{array}$ & 200 & $\begin{array}{c}X_{(1)}^{2}=20.736 \\
P<0.001\end{array}$ & Significant \\
\hline Non-exposed group & $\begin{array}{l}10 \\
(5)\end{array}$ & $\begin{array}{l}191 \\
(95)\end{array}$ & 201 & - & - \\
\hline Total & 50 & 351 & 401 &. &. \\
\hline
\end{tabular}

Tongue pigmentation was more $(20 \%)$ in the arsenic exposed group and less $(5 \%)$ in the non-exposed group (table-4). The differences in the proportion of having pigmentation on tongue among the arsenic exposed and non-exposed groups were found statistically significant by Pearson Chi-Square $\left(\mathrm{x}^{2}\right)$ at $1 \mathrm{df}$.
Table-5: Distribution of Respondents by oro-dental problem as Tooth Abrasion.

\begin{tabular}{|c|c|c|c|c|c|}
\hline \multirow{2}{*}{$\begin{array}{l}\text { Categories according } \\
\text { to Arsenic exposure }\end{array}$} & \multicolumn{3}{|c|}{ Oro-dental problem as Tooth Abrasion } & \multirow{2}{*}{$\begin{array}{c}\text { Test of } \\
\text { significance }\end{array}$} & \multirow{2}{*}{ Comment } \\
\hline & Yes & No & Total & & \\
\hline Exposed group & $\begin{array}{l}48 \\
(24)\end{array}$ & $\begin{array}{l}152 \\
(76)\end{array}$ & 200 & $\begin{array}{c}X_{(1)}^{2}=31.333 \\
P<0.001\end{array}$ & Significant \\
\hline Non-exposed group & $\begin{array}{c}9 \\
(4.5)\end{array}$ & $\begin{array}{c}192 \\
(95.5)\end{array}$ & 201 & - & - \\
\hline Total & 57 & 344 & 401 & - & $\cdot$ \\
\hline
\end{tabular}

Arsenic exposed group had more (24\%) teeth abrasion than the non-exposed group (4.5\%) (table-5). The differences in the proportion of having teeth abrasion among the arsenic exposed and non-exposed groups were found statistically significant by Pearson ChiSquare $\left(x^{2}\right)$ at $1 \mathrm{df}$.

Table-6: Distribution of Respondents by oro-dental problem as Dental Caries.

\begin{tabular}{|c|c|c|c|c|c|}
\hline \multirow{2}{*}{$\begin{array}{l}\text { Categories according } \\
\text { to Arsenic exposure }\end{array}$} & \multicolumn{3}{|c|}{ Oro-dental problem as Dental Caries } & \multirow{2}{*}{$\begin{array}{c}\text { Test of } \\
\text { significance }\end{array}$} & \multirow{2}{*}{ Comment } \\
\hline & Yes & No & Total & & \\
\hline Exposed group & $\begin{array}{c}37 \\
(18.5)\end{array}$ & $\begin{array}{c}163 \\
(81.5)\end{array}$ & 200 & $\begin{array}{l}X_{(1)}^{2}=3.15 \\
P<0.05\end{array}$ & $\begin{array}{c}\text { insignifica } \\
\text { nt }\end{array}$ \\
\hline Non-exposed group & $\begin{array}{c}52 \\
(25.9)\end{array}$ & $\begin{array}{c}149 \\
(74.1)\end{array}$ & 201 & - & - \\
\hline Total & 89 & 312 & 401 & . & $\cdot$ \\
\hline
\end{tabular}

Table- 6 delineates that the dental caries was found more (25.9\%) among the arsenic non-exposed group than the exposed group (18.5\%). The differences in the proportion of having dental caries among the arsenic non-exposed and exposed groups were found statistically significant by Pearson Chi-Square $\left(x^{2}\right)$ at $1 \mathrm{df}$.

\section{Discussion:}

A total of 400 respondents were interviewed through structured questionnaire and among them, 200 were exposed to arsenic in drinking water. For comparison, non-exposed group of 200 respondents were interviewed and examined. On examination, pigmentation on gingiva was found more $(24.5 \%)$ among the arsenic exposed group and less (10.9\%) among the non-exposed group. The differences in the proportion of having gingival pigmentation among these two groups were found statistically significant. According to Pearson Chi-Square $\left(x^{2}\right)$ at $1 \mathrm{df}$; these data suggested that there was a significant association between consumption of arsenic contaminated water and development of gingival pigmentation $(p<0.01)$. 
Recent study showed that $94.5 \%$ gingival pigmentation found among the arsenic exposed adult group where non-exposed adult group had only $44.5 \% .13,14$ This study showed that the dental caries was more (25.9\%) among the arsenic non-exposed group than the exposed group (18.5\%) (table-6). Previously study showed that $70 \%$ dental caries was found among the arsenic nonexposed adult group and $55 \%$ among the arsenic exposed adult patient. ${ }^{17}$

The study also revealed that teeth sensitivity was found $6 \%$ among the arsenic exposed group and $1 \%$ among arsenic non-exposed group (table-2). The differences in the proportion of having teeth sensitivity among the arsenic exposed and arsenic non-exposed groups were found statistically significant by Pearson Chi-Square $\left(x^{2}\right)$ at $1 \mathrm{df}$. About $24 \%$ arsenic exposed patients had tooth abrasion, whereas, only $4.5 \%$ had abrasion in the nonexposed group (table-5). The differences in the proportion of having tooth abrasion among arsenic exposed and arsenic non-exposed group were found statistically significant by Pearson Chi-Square ( ) at $1 \mathrm{df}$. A recent study showed that $19 \%$ abrasion found among the arsenic exposed patient group and only $2.5 \%$ among the non-exposed group but also higher $(9 \%)$ in arsenic exposed non-patient group. ${ }^{17}$

Gingival swelling, Gingival pigmentation, buccal mucosal pigmentation, tongue pigmentation, palatal pigmentation were found statistically significant (table-3 \& 4). According to Pearson Chi-Square $\left(x^{2}\right)$ at $1 \mathrm{df}$; data suggested that there was a significant association between consumption of arsenic contaminated water and development of above mentioned oro-dental problems. Gingival pigmentation, tongue pigmentation, buccal mucosal pigmentation and palatal pigmentation were also found statistically significant in recent study done among adult group. ${ }^{8}$

Toxic effect of fluoride was not influenced by arsenic in the respect there was a case control study which showed that the student who had lived in the arsenic endemic area had higher prevalence of enamel hypoplasia, lower caries experiences and higher percentage of children who were free from periodontal diseases that those of the control group.16 This study also showed that enamel hypoplasia were more among arsenic exposed respondents then non-exposed group and caries were less in the arsenic exposed group (data is not shown).

Thus, it may be a tool for early diagnosis of the arsenicosis. Findings of this study will encourage for broad-based well-designed study in this field conducted particularly on enamel hypoplasia and attributing abrasion as consistent sign for arsenicosis and also applicable for carries, buccal mucosal pigmentation and tongue pigmentation. ${ }^{10}$

\section{Conclusions:}

It was observed from this study that there was the tendency of developing tooth abrasion, swelling of gingiva and pigmentation of buccal mucosa, tongue, palate and gingiva among the arsenic exposed group. Arsenic might have influence on low tendencies of occurring caries. Further broad-based well-designed studies in this field thus help to find out the facts and take appropriate measures to handle the situation.

\section{References:}

1. Ahmad SA. Water contamination and health hazard. 1st ed. Udayan press, Rajshahi; 2000:73.

2. Punyasingh K, Bhuvapanich V, Weerapradist W. Effect of chronic exposure of arsenic on oral health of school children. Mahidol Dent J 1990;10(3):121-27.

3. Chowdhury QI. Milions are at risk from arsenic contamination. Bangladesh NEMAP News letter 1999;3:1-2.

4. National Arsenic Mitigation Information Centre (NAMIC). [online]. 2004. [cited 2005 April 20]; Available from URL:http//www./bamwsp.org

5. Cerbian ME, Albores A, Aguilar M, et al. Chronic arsenic poisoning in the North Mexico. Human Toxicol 1983;2:121-33.

6. Borgono JM, Venturino H, Vicent P. Clinical and epidemiological study of arsenicism in northern Chile. Revista Medica De Chile 1980;180:1039-48.

7. Cebrian ME. Some potential problems in assessing the effects of chronic arsenic exposures in North Mexico. American Chemical Society. Division of environmental chemistry; 194th meeting 1987;27:114-16.

8. Ahmed F. Arsenic removal from tube well water. The 3rd forum on arsenic contamination of ground water in Asia;1998:59-62.

9. Arsenic established carcinogen. [online]. 2004 Dec. [cited 2005 June 3]; Availabe from URL:http://www.sosarsenic.net/English/arsenic/

10. Arsenic environmental health citeria 18. World Health Organization, Geneva; 1981.

11. Arnold W. Arsenic In. Seiller GH and Segel H, eds. Handbook on toxicity of inorganic compounds. Marcel Dekkher INC.; 1998:79-93.

12. Kabir MI, Rahaman M, Flora MS, et al. Arsenicosis and Body Mass Index (BMI) in a selected area of Bangladesh. J Prev Social Med 2001;20(1):6-12.

13. Hadi A, Parveen R. Arsenicosis in Bangladesh: preventive and socioeconomic correlates. Public Health 2004:559-564.

14. Dhar RK, Biswas BK, Samanta G, et al. Ground water arsenic calamity in Bangladesh. Curr Sc 1997;73(1):48-59.

15. Towards an assessment of the socioeconomic impact of arsenic poisoning in Bangladesh. World health organization 2000:3-27.

16. Mazumder DNG. Clinical aspect of chronic arsenic toxicity. JAPI 1999;49:650-54.

17. Dickerson OB. Antimony, arsenic and their compounds. In: Zenz C, Dickerson OB and Horvati EP, eds. Occupational Medicine. 3rd ed. Missouri:Mosby;1994:466-73.

City Dent. Coll. J Volume-10, Number-1, January-2013 